\title{
Bioremediation of Heavy Metal Pollution by Nano-Particles of Noaea Mucronata
}

\author{
Fariba Mohsenzadeh and Abdolkarim Chehregani Rad
}

\begin{abstract}
Environmental pollution with heavy metals is a common problem in many countries. Great efforts have been made in the last two decades to reduce pollution sources and remedy the polluted soil and water resources. A field study was conducted in a dried waste pool of a Lead mine in Zanjan (Iran) to find the native accumulator plant(s). Concentrations of heavy metals were determined both in the soil and the plants that were grown in a dried waste pool by using flame atomic absorption method. The concentration of total $\mathrm{Cu}, \mathrm{Zn}, \mathrm{Pb}$ and $\mathrm{Ni}$ were found to be higher than that natural soil and the toxic levels. The results showed that six dominant vegetation namely Centaurea virgata, Gundelia tournefortii, Scariola orientalis, Rreseda lutea, Noaea mucronata and Eleagnum angustifolia accumulated heavy metals. Based on the results, it was concluded that Noaea mucronata belonging to Chenopodiaceae is the best $\mathbf{P b}$ accumulator and also a good accumulator for $\mathrm{Zn}$, $\mathrm{Cu}$ and $\mathrm{Ni}$, but the best $\mathrm{Fe}$ accumulator is Reseda lutea and the best one for $\mathrm{Cd}$ is Marrobium vulgare. The bioaccumulation ability of nano-particles prepared from $N$. mucronata was evaluated in experimental water containers. The study showed that the amount of heavy metals in polluted water decreased several times during three days bioremediation. Based on the obtained data, $N$. mucronata is an effective accumulator plant and its nano-particles are useful for watery media detoxification and bioremediation in critical conditions.
\end{abstract}

Index Terms-Heavy metal pollution, detoxification, metal accumulator plants, phytoremediation.

\section{INTRODUCTION}

Heavy metals are released into the environment as a result of human activities such as mining, smelting, electroplating, energy and fuel production, power transmission, intensive agriculture, sludge dumping, and melting operations [1].

Land and water are precious natural resources on which rely the sustainability of agriculture and the civilization of mankind. Unfortunately, they have been subjected to maximum exploitation and severely degraded or polluted due to anthropogenic activities. The pollution includes point sources such as emission, effluents and solid discharge from industries, vehicle exhaustion and metals from smelting and mining, and nonpoint sources such as soluble salts (natural and artificial), use of insecticides/pesticides, disposal of industrial and municipal wastes in agriculture, and excessive use of fertilizers [2-4]. All the heavy metals at high concentrations have strong toxic effects and are regarded as environmental pollutants [2]. Proper management of plants in such areas may significantly contribute to restoring the

Manuscript received January 2, 2012; revised February 28, 2012.

The Authors are with Department of Biology, Bu-Ali Sina University, Hamedan, Iran (e-mail: fmohsenzade@gmail.com). natural environment. Sawidis [5] showed that heavy metals have toxic effect on the pollen growth and pollen tube growth and cause to be a range of strong morphological abnormalities, characterized by uneven or aberrant growth, including apical branching or swelling at the tip of the pollen tube. Several researchers also showed toxic effects of heavy metals on different organisms [6-8].

Numerous efforts have been undertaken recently to find methods of removing heavy metals from soil, water and other environmemts, such as phytoremediation [9, 10]. Plant vegetation plays an increasingly important ecological and sanitary role for chemically polluted lands [9]. Proper management of plants in such areas may significantly contribute to restoring the natural environment. Perhaps, not surprisingly, phytoremediation was initially proposed as an environmental cleanup technology for the remediation of metal-contaminated water and soil [11- 14]. The identification of metal hyperaccumulators, plants capable of accumulating extraordinar high metal levels, demonstrates that plants have the genetic potential to clean up contaminated soil. Phytoremediation has recently become a subject of public and scientific interest and a topic of many recent research $[1,9,15]$. The Ability of selecting species of plants, which are either resistant to heavy metals, or can accumulate great amounts of them, would certainly facilitate reclamation of contaminated areas [16-21].

Phytoremediation is a cost-effective technology for environmental cleaning. We need new and variable accumulator plants for phytoremediation in different climates and conditions, so new studies are still necessary to find new accumulator plants for using in different conditions. With this idea, the aim of this study was to elucidate or verify accumulating ability of plants that were grown in the polluted sites of a lead and zinc mine (Angouran, Iran) and to evaluate their phytoremediation ability for waste water refining.

\section{MATERIAL AND METHODS}

\section{A. Studied Area}

The dried waste pool of the mines should be considered as high concentrated metal sources because the sedimentations of wastewater resulted from washing processes of mining were stored in ponds and then dried. An artificial old dried waste pool of a Lead mine, located in Angouran, Zanjan in Iran, was studied as a polluted area in this research. The dried sediments are similar to natural soil but with a high metal concentration. The Plants grown in this area were collected and their scientific names and characteristics were determined. The concentration of heavy metals was 
determined in the waste pool soil and was compared with the natural soil. The amount of heavy metals was determined in different parts (shoots and leaves) of the plants. The plants with high concentration of heavy metals were chosen as accumulators.

\section{B. Heavy Metal Determination}

Heavy metals were determined in soil samples of the sediment of the waste pool that was regarded as a polluted soil and the soil samples of $5 \mathrm{Km}$ further than the mine site were regarded as natural soil. At each subjected plot, 10-15 samples of the soil (depth 10-15 cm) were taken and sieved through a $1 \mathrm{~cm}$ sieve. To estimate the total heavy metals in the plants, samples (shoots and leaves) were dried at $105{ }^{\circ} \mathrm{C}$ for $24 \mathrm{~h}$ in acid-washed and reweighed volumetric $100 \mathrm{ml}$ Pyrex conical flasks. The content (about $1 \mathrm{~g}$ ) was digested in $20 \mathrm{ml}$ of boiling concentrated $(65 \%)$ nitric acid (especially made pure for spectroscopy). The solution was boiled in a hot plate until light fumes were given off. Next, the samples were cooled down and the digests were filled up to $100 \mathrm{ml}$ with deionized water and left overnight to allow the remaining soil particles to settle out of the suspension. Finally, $20 \mathrm{ml}$ of each sample solution was used for heavy metal concentration measurements, using the flame atomic absorption method for $\mathrm{Pb}, \mathrm{Cu}$, and $\mathrm{Zn}$ and graphite furnace technique for $\mathrm{Cd}$ measurement (Aanalyst 800, Perkin-Elmer). The accumulator plants were identified regarding the concentration of heavy metals in the subjected plants.

\section{Evaluation of Metal Removing}

Noaea mucronata, used as an accumulator plant for this study, belongs to Chenpodiaceae and because it is common the main area and its accumolatng ability is considerable. Its roots and shoots were blended until fine particles formation. Nano-particles of the powder were collected by passing through a mesh with pores of $0.2-2 \mu \mathrm{m}$ and used for heavy matals removing from watery metal-polluted media.

Fifty pots were selected and filled with $15 \mathrm{~kg}$ water. They were devided in to five groups and each group was chosen for a metal removing experiment. In ten pots (group A) water contained Cadmim with the concenteration samed with the waste water (54 ppm). In ten pots (group B) Cupper was added in the concentration of $123 \mathrm{ppm}$. In three other groups (C, D, E) the concentrations of $\mathrm{Ni}, \mathrm{Pb}$ and $\mathrm{Zn}$ were 98, 14800 and $2950 \mathrm{ppm}$ respectively. In each pot Noaea mucronata plant nano-particles ( $500 \mathrm{~g}$ ) was added. After three days, the particles were removed by using a double layer of Watman filter paper after No. 4. Heavy metals were determined in the water of the pots, before the beginning of the study and also after three days treatment with the above mentioned particles.

\section{RESULTS}

\section{A. Determination of Heavy Letals in the Soil}

This research studied the flora of waste pool of Angouran mine that is the largest lead and zinc mine in Iran located in Zanjan province (Fig. 1). The evaluation of heavy metal in the soil of the waste pool and the natural soil $(5 \mathrm{~km}$ away from the mine) showed that the amount of some heavy metals in the waste pool of the mine were several times higher than the natural areas (Table 1).

TABlE I: Concentration of Some Heavy Metals (PPM) in Waste pool of ANGouran Lead And Zinc Mine and Natural SoIl (Out OF Mine). The Date Showed That Amounts of Most Studied Metals in Waste Pool Soils Are Several Times Higher Than Natural Soils. Each Data REPRESENTED THE MEANS \pm SE OF 12 SAMPLES. DifFERENTIATIONS BETWEen WASTE POOL AND NATURAL SOILS ARE SignifiCANT $(\times \mathrm{P}<0.01, \times \times \mathrm{P}<0.05)$ ${ }^{*}$ The samples prepared out of the mine site

\begin{tabular}{|l|l|l|l|l|l|l|}
\hline & Cd & Cu & Fe & Ni & Pb & Zn \\
\hline $\begin{array}{l}\text { Waste pool } \\
\text { soil }\end{array}$ & ${ }^{\times \times} 81.10 \pm 6.8$ & ${ }^{\times} 162 \pm 9.5$ & $1730 \pm 95$ & $1730 \pm 95$ & ${ }^{\times} 16700 \pm 2750$ & ${ }^{\times} 2950 \pm 155$ \\
\hline${ }^{*}$ Natural soil & $0.20 \pm 0.18$ & $10.00 \pm 1.80$ & $80 \pm 12.4$ & $78.00 \pm 9.70$ & $67 \pm 24$ & $181 \pm 37$ \\
\hline
\end{tabular}

\section{B. Results of Heavy Metal Accumulator Recognition}

This research studied the flora of a Lead Mine located in Angouran, Zanjan, Iran. Plants that were more popular and could grow at the waste pool of the mine were collected and analyzed for their scientific name and classification. The determinations of the heavy metals in plant shoots showed that some of them acted as accumulators and are illustrated in table 2.

Results showed that the amounts of Cadmium in some plants, including Marrubium vulgar, Onosma kotschyi, Hultemia persica, Stipa lessingiana, Salix excelsa, Centaurea virgata and Reseda lutea, were more than others (Table 2). Marrubium vulgar is, however, the best $\mathrm{Cd}$ accumulator plant (9 ppm). The study indicated that the best $\mathrm{Cu}$ accumulator plant was Euphorbia macroclada (65 ppm) but some species including Centaurea virgata, Scariola orientalis and Cirsium congestum_also accumulated $\mathrm{Cu}$ considerably. Analyzing the amount of $\mathrm{Fe}$ in the experimental plants showed that we can consider Reseda lute $a$ as the best Fe accumulator (5490 ppm) but the amount of $\mathrm{Fe}$ in Euphorbia macroclada, Centaurea virgata and Gundelia tourneforti was also more than the other studied plants (Table 2).

The amount of Ni in most of the studied plants was lower than the toxic level and was lower than that of the natural soil as well. Results showed that the best $\mathrm{Zn}$ accumulator overall was Euphorbia macroclada (1873 ppm), while Reseda lutea, Salix excelsa, Scariola orientalis and Cynedon dactylon were other accumulators. Among the studied plants the best $\mathrm{Pb}$ accumulator was Euphorbia macroclada (1138 ppm), meanwhile Centaurea virgata, Scariora orientalis and Cardaria draba also accumulated $\mathrm{Pb}$ relatively (Table 2). 


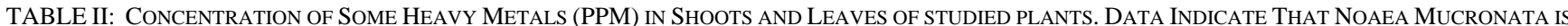
THE BEST ACCUMULATOR FOR PB AND Also FOR ZN, Cu AND NI. THE SPECIES THAT ACCUMUlATED High AMOUNT OF Fe Is RESEDA LUTEA AND NI IS MAROBIUM VULGAR. EACH DATA REPRESENTED THE MEANS \pm SE OF 10-15 SAMPLES. BOLDED DATA REPRESENT SPECIES THAT ACCUMULATED THE HIGHEST AND SigNifiCANT AMOUNT OF EACH METAL $(* \mathrm{P}<0.01, * * \mathrm{P}<0.05)$.

\begin{tabular}{|c|c|c|c|c|c|c|}
\hline Species & Cd & $\mathrm{Cu}$ & $\mathrm{Fe}$ & $\mathrm{Ni}$ & $\mathbf{P b}$ & $\mathbf{Z n}$ \\
\hline Achillea filipendalina & $2.00 \pm 0.18$ & $40.00 \pm 6.2$ & $1479 \pm 324$ & $6.00 \pm 0.8$ & $135.00 \pm 32$ & $38.00 \pm 6.1$ \\
\hline Biebersteinia multifida & $7.00 \pm 0.9$ & $20.00 \pm 4.5$ & $480 \pm 91$ & $4.00 \pm 0.8$ & $23.00 \pm 3.5$ & ND \\
\hline Cardaria draba & $2.40 \pm 0.2$ & $26.40 \pm 3.5$ & $1324 \pm 245$ & $8.40 \pm 1.2$ & $776.00 \pm 105$ & $1600.00 \pm 185$ \\
\hline Cenecio glaocus & $5.50 \pm 0.6$ & $16.50 \pm 4.6$ & $1324 \pm 245$ & $8.40 \pm 1.2$ & $776.00 \pm 105$ & $1600.00 \pm 185$ \\
\hline Centaurea virgate & $2.20 \pm 0.2$ & $36.65 \pm 4.5$ & $944 \pm 186$ & $6.30 \pm 0.9$ & $590.00 \pm 121$ & $1262.00 \pm 145$ \\
\hline Chenopodium album & $1.60 \pm 0.4$ & $22.20 \pm 2.9$ & $340 \pm 46$ & $11.93 \pm 1.9$ & $214.33 \pm 35$ & $598.67 \pm 106$ \\
\hline Cydonia oblonga & $1.80 \pm 0.2$ & $22.93 \pm 4.2$ & $460 \pm 74$ & $7.40 \pm 1.2$ & $310.67 \pm 45$ & $1428.00 \pm 240$ \\
\hline Dendrostellaria lessertii & $2.00 \pm 0.17$ & $28.00 \pm 5.7$ & $800 \pm 214$ & $7.00 \pm 1.7$ & $353.00 \pm 65$ & $139.00 \pm 22$ \\
\hline Eleagnus angustifolia & $0.80 \pm 0.06$ & $9.60 \pm 1.6$ & $148 \pm 38$ & $5.20 \pm 0.65$ & $404.00 \pm 78$ & $980.00 \pm 156$ \\
\hline Gundelia tournefortii & $2.30 \pm 0.25$ & $24.00 \pm 3.8$ & $1952 \pm 316$ & $8.40 \pm 1.3$ & $652.00 \pm 86$ & $820.00 \pm 14.3$ \\
\hline Hultemia persica & $3.00 \pm 0.5$ & $23.00 \pm 2.5$ & $580 \pm 67$ & $8.00 \pm 1.5$ & $62.00 \pm 9.5$ & $48.00 \pm 7.5$ \\
\hline Leutea petidaris & $3.00 \pm 0.25$ & $19.00 \pm 2.5$ & $246 \pm 39$ & $4.00 \pm 0.7$ & $25.00 \pm 4$ & -- \\
\hline Marrubium vulgare. & $9.00 \pm 1.2$ & $34.00 \pm 3.1$ & $540 \pm 95$ & $4.00 \pm 0.65$ & $78.00 \pm 12$ & $58.00 \pm 9.4$ \\
\hline Myostis caespitosa & $2.00 \pm 0.16$ & $24.00 \pm 3.1$ & $80 \pm 34$ & $5.00 \pm 0.6$ & $61.00 \pm 9.5$ & $62.00 \pm 10.5$ \\
\hline Noaea mucronata & $7.25 \pm 0.5$ & ${ }^{* * *} 72.00 \pm 8.5$ & $11230 \pm 142$ & $12.50 \pm 3.5$ & * $1056.00 \pm 164$ & ${ }^{*} 1645.00 \pm 114$ \\
\hline Onosma kotschyi & $3.00 \pm 0.5$ & $47.00 \pm 7.6$ & $160 \pm 48$ & $6.00 \pm 1.1$ & $39.00 \pm 6$ & $151.00 \pm 25$ \\
\hline Reseda lutea & $5.50 \pm 1.1$ & $57.50 \pm 8.5$ & ${ }^{*} 5490 \pm 980$ & $7.00 \pm 1.3$ & $371.50 \pm 57$ & $233.00 \pm 36$ \\
\hline Salix excels & $3.93 \pm 0.9$ & $35.13 \pm 4.8$ & $1891 \pm 344$ & $9.13 \pm 1.6$ & $404.00 \pm 65$ & $685.67 \pm 95$ \\
\hline Scariola orientalis & $2.60 \pm 0.4$ & $43.40 \pm 5.9$ & $1000 \pm 245$ & $8.60 \pm 1.4$ & $884.00 \pm 141$ & $1468.00 \pm 160$ \\
\hline Smymium cordifolium & $3.00 \pm 0.5$ & $24.90 \pm 3.5$ & $400 \pm 67$ & $7.00 \pm 0.9$ & $4.00 \pm 0.5$ & $20.00 \pm 3.2$ \\
\hline Stipa lessingiana & ND & $22.50 \pm 3.5$ & $673.5 \pm 148$ & $7.50 \pm 1.2$ & $68.00 \pm 11$ & $39.50 \pm 6.5$ \\
\hline Ziziphora tenuior & $4.00 \pm 0.6$ & $50.00 \pm 6.8$ & $1060 \pm 168$ & $7.00 \pm 0.9$ & $228.00 \pm 35$ & $55.00 \pm 9.5$ \\
\hline
\end{tabular}

\section{The Bioremediation Results}

Noaea mucronata was chosen as an accumulator in this study because it is a common plant in the studied polluted area and can effectively accumulate most of the studied heavy metals (Table 2). Its nano-particles were used for bioremediation of heavy metal polluted water. The data showed that the concentrations of all the heavy metals decreased considerably after three days remediation. The decrease in $\mathrm{Pb}, \mathrm{Cd}, \mathrm{Ni}, \mathrm{Cu}$ and $\mathrm{Zn}$ are illustrated in figures 1-5. The data showed that the decrease of $\mathrm{Pb}$ in experimental pots was more than the other metals (\%98). Meanwhile, the decrease of other heavy metals was also considerable (Cd, \%72.04; Zn, \%79.03; Ni, \%33.61; Cu, \%73.38).

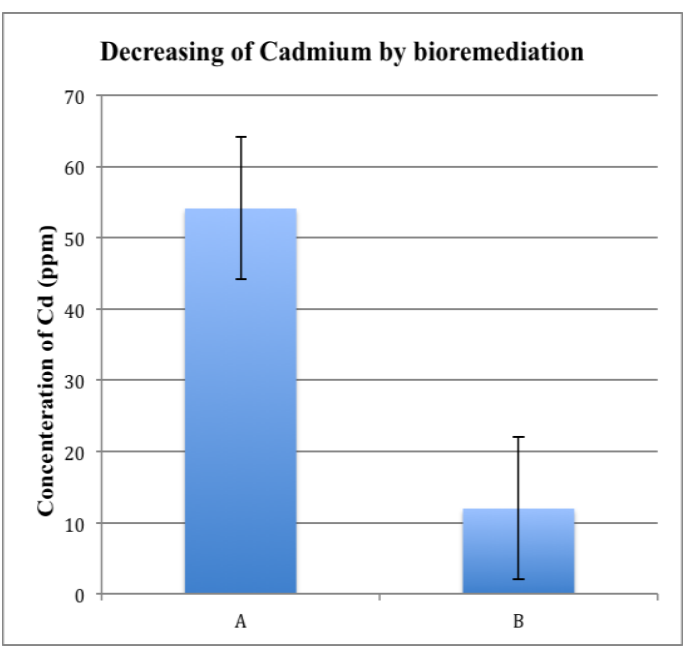



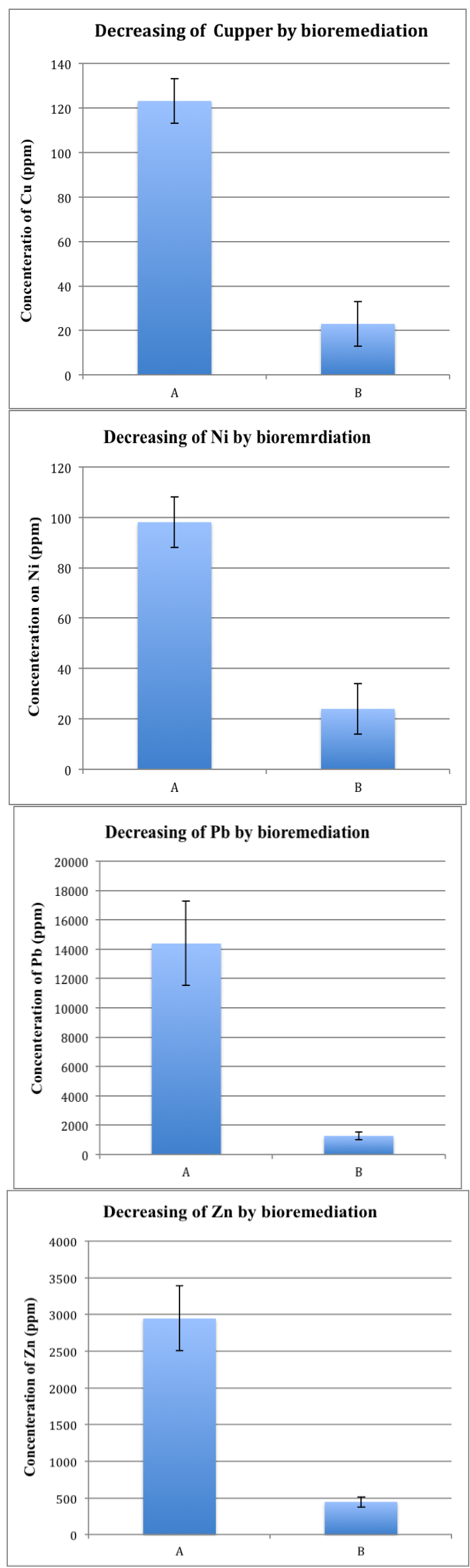

Fig. 1. Comparison between concentration of some heavy metals (ppm) in the polluted water before (A) and after bioremediation (B) by nano-particles of Noaea mucronata. Data indicate that amounts of all studied heavy metals were decreased due to bioremediation. Decreasing of metal concentration in experimental groups is significant $(\mathrm{P}<0.01)$. Each data represent the means \pm SE of 10 samples.

\section{DISSCUSION}

Heavy metals contamination of arable soil showed several problems, including phytotoxic effects of certain elements such as $\mathrm{Cd}, \mathrm{Pb}, \mathrm{Zn}$ and $\mathrm{Cu}$ which are well known as micronutrients and cause several phytotoxicities if critical endogenous levels are exceeded [2,6]. All heavy metals at high concentrations have strong toxic effects and are regarded as environmental pollutants $[6,7,8]$.

According to the results of the following study, the plants mentioned below can be regarded as heavy metal accumulators while they are different regarding their accumulating ability: Noaea mucronata, Reseda lutea, Salix excelsa, Scariola orientalis, Chenopodium album, Cydonia oblonga, and Centaurea virgata (Table2). To conclude, $N$. mucronata should be considered as the best and the right $\mathrm{Pb}$ accumulator plant (according to Baker et al. $[12,13]$ ) because it accumulated more than $1000 \mathrm{ppm}$.

N. mucronata was selected as a good metal accumulator especially a good $\mathrm{Pb}$ accumulator, and then it was chosen for metal remediation. Its ability to remove heavy metals from polluted water has been evaluated as well. The nano-particles provided from $N$. mucronata plants were kept in experimental pots for three days and then the particles were removed by filteration and the amount of the heavy metals were compared with the prior bioremediation. The data showed that the concentrations of all the subjected metals decreased (Pb, 92\%; $\mathrm{Zn}, 76.05 \%$; $\mathrm{Cu}, 74.66 \%$; Cd, 69.08\%; $\mathrm{Ni}, 31.50 \%$ ) among which $\mathrm{Pb}$ showed the highest decrease (Figure 1). Nano-particles of E. macroclada is suggested for removing and detoxification of heavy metals, (especially $\mathrm{Pb}$, $\mathrm{Cd}, \mathrm{Cu}$ and $\mathrm{Zn}$ ), from polluted environments [20,21].

\section{CONCLUSION}

The results of this research work showed that some plants were able to accumolate heavy metals considerably. Such plant species are interested for bioremediation of heavy metal-polluted areas and media. Nano-particles provided fron Noaea mucronata, as the most effective accumolator plant, were used for removing some heavy metals from polluted water. Results indicated that the nano-particles of $N$. mucronata are useful for watery media detoxification and bioremediation in critical conditions.

\section{AKNOWLEDGMENT}

This research was done using a research grant provided by the Research Concile of Bu-Ali Sina University.

\section{REFFERENCES}

[1] J. C. Igwe and A. A. Abia. "A bioseparation process for removing heavy metals from waste water using biosorbents." African J. of Biotechnol. 2006, vol. 5, pp. 1167-1179.

[2] S. P. McGrath. "Adverse effects of cadmium on soil microflora and fauna. In: McLaughlin MJ, Singh BR (eds) Cadmium in soils and plants.” Kluwer Academic, Dordrecht, 1999, pp. 199-218.

[3] J. O. Nriagu and J.M. Pacyna. "Quantitative assessment of worldwide contamination of air, water and soils by trace metals." Nature, 1988, vol. 333, pp. $134-139$.

[4] B. Eduardo Schalscha and T. Ines Ahumada. "Heavy metals in rivers and soils of central Chile." Water Science and Technology, 1988, vol. 37, pp. 251-255 
[5] T. Sawidis. "Effect of cadmium on pollen germination and tube growth in Lilium longiflorum and Nicotiana tabacum." Protoplasma. 2008, vol. 233, pp. 95-106.

[6] A. Chehregani, B. Malayeri, and R. Golmohammadi. "Effect of heavy metals on the developmental stages of ovules and embryonic sac in Euphorbia macroclada." Pakistan J. Biol Sci. 2004, vol. 8, pp. 622-625.

[7] N. Yousefi, A. Chehregani, B. Malayeri, B. Lorestani, and M. Cheraghi "Investigating the Effect of Heavy Metals on Developmental Stages of Anther and Pollen in Chenopodium botrys L. (Chenopodiaceae)." Biological Trace Element Research, 2011, vol. 140, pp. 368-376.

[8] F. Mohsenzadeh, A. Chehregani, and N. Yousefi. "Effect of the Heavy Metals on Developmental Stages of Ovule, Pollen, and Root Proteins in Reseda lutea L. (Resedaceae)." Biological Trace Element Research, 2011, Online published.

[9] J. Antonkiewicz and C. Jasiewicz. "The use of plants accumulating heavy metals for detoxification of chemically polluted soils." $J$. of Polish Agricultural Unive, 2002, vol. 5, pp. 121-143.

[10] M. Horsfall and A. Spief. "Effect of temperature on the sorption of $\mathrm{Pb}^{2+}$ and $\mathrm{Cd}^{2+}$ from aqueous Solution by caladium bicolor (wild cocoyam) biomass." Electronic Journal of Biotechnology [online]. 2005. 8(2) Available from Internet: http://www.ejbiotechnology.info/content/vol8/issue2/4/index.html ISSN: 0717-3458.

[11] R. L. Chaney "Plant uptake of inorganic waste." In Land Treatment of Hazardous Wastes. Edited by Parr J. E., Marsh P. B., Kla J. M. Park Risge: Noyes Data Corporation. 1983, pp. 50-76.

[12] A. J. M. Baker, R.D. Reeves, and S.P. Mc Granth. "In situ decontamination of heavy metal polluted soils using crops of metal-accumulating plants- a feasibility study." 1991, pp: 600-605. In R.E. Hinchee and R.F. Oflenbuttle (eds), In Situ Bioreclamation:
Applications and Investigations for Hydrocarbon and Contaminated Site Remediation. Battelle Memorial Institute, Columbus, $\mathrm{OH}$ Buttereworth-Heinemann, Boston, MA.

[13] A. Baker, S.P. Mc Granth, C.M.D. Sidoli, and D. Reevers. "The potential for heavy metal decontamination." Mining Environ. Manag. 1995, vol. 3, pp. 12-14.

[14] C. Keller, D. Hammera, and A. Kayserb. "Phytoextraction of Cd and $\mathrm{Zn}$ with Thalaspi caerulescens and Salix viminalis in field trials." Meeting in Stockholm, Sweden: Workshop "Phytoremediation of toxic metals" June, pp. 12-15, 2003.

[15] L. Raskin, R. D. Smith, and E. Saltd. "Phytoremediation of metals using plants to remove pollutants from the environment." Current Opinion in Biotech. 1997, vol. 8, pp. 221-226.

[16] S. Bizly, C. L. Rugh, and R. B. Meager. "Efficient phytodetoxification of the environmental pollutant methylmercury by engineered plants." Nat. biotechnol. 2000, vol. 18, pp. 213-217.

[17] M. M. Lasat. "Phytoextraction of toxic metals, a review of biological mechanisms." Journal of environmental quality, 2002, 31: 109-120.

[18] S. Susarla, V. F. Miedina, and S. C. Mc Cutcheon. "Phytoremediation an ecological solution to organic chemical contamination." Ecol Engin. 2009, vol. 18, pp. 647-658.

[19] T. V. Nedelkoska and P. M. Doran. "Characteristics of heavy metal uptake by plant species with potential for phytoremediation and phytomining." Mineral Engin. 2000, vol. 13, pp. 549-561.

[20] H. Dahmani- Muller, F. Van Oort, B. Gelie, and M. Balabane. "Strategies of heavy metal uptake by three plant species growing near a metal smelter." Environ. Pollut. 2000, vol. 109, pp. 231-238.

[21] D. E. Salt, M. Blaylock, P. B. A. N. Kumar, V. Dushenkov, B. D. Ensley, and I. C. Raskin. "Phytoremediation: a novel strategy for the removal of toxic metals from the environment using plants." Biotechnology. 1995, vol. 13, pp. 468-474. 